\title{
Inhibition of Krebs Cycle Enzymes by Hydrogen Peroxide: A Key Role of $\alpha$-Ketoglutarate Dehydrogenase in Limiting NADH Production under Oxidative Stress
}

\author{
Laszlo Tretter and Vera Adam-Vizi \\ Department of Medical Biochemistry, Neurochemical Group, Semme/weis University of Medicine, \\ Budapest, $\mathrm{H}-1444$, Hungary
}

In this study we addressed the function of the Krebs cycle to determine which enzyme(s) limits the availability of reduced nicotinamide adenine dinucleotide (NADH) for the respiratory chain under $\mathrm{H}_{2} \mathrm{O}_{2}$-induced oxidative stress, in intact isolated nerve terminals. The enzyme that was most vulnerable to inhibition by $\mathrm{H}_{2} \mathrm{O}_{2}$ proved to be aconitase, being completely blocked at $50 \mu \mathrm{M}$ $\mathrm{H}_{2} \mathrm{O}_{2}$. $\alpha$-Ketoglutarate dehydrogenase $(\alpha-\mathrm{KGDH})$ was also inhibited but only at higher $\mathrm{H}_{2} \mathrm{O}_{2}$ concentrations $(\geq 100 \mu \mathrm{M})$, and only partial inactivation was achieved. The rotenone-induced increase in reduced nicotinamide adenine dinucleotide (phosphate) $[\mathrm{NAD}(\mathrm{P}) \mathrm{H}]$ fluorescence reflecting the amount of $\mathrm{NADH}$ available for the respiratory chain was also diminished by $\mathrm{H}_{2} \mathrm{O}_{2}$, and the effect exerted at small concentrations $(\leq 50 \mu \mathrm{M})$ of the oxidant was completely prevented by 1,3-bis(2-chloroethyl)-1-nitrosourea $(\mathrm{BCNU})$, an inhibitor of glutathione reductase. BCNUinsensitive decline by $\mathrm{H}_{2} \mathrm{O}_{2}$ in the rotenone-induced $\mathrm{NAD}(\mathrm{P}) \mathrm{H}$ fluorescence correlated with inhibition of $\alpha$-ketoglutarate dehy- drogenase. Decrease in the glutamate content of nerve terminals was induced by $\mathrm{H}_{2} \mathrm{O}_{2}$ at concentrations inhibiting aconitase. It is concluded that (1) aconitase is the most sensitive enzyme in the Krebs cycle to inhibition by $\mathrm{H}_{2} \mathrm{O}_{2}$, (2) at small $\mathrm{H}_{2} \mathrm{O}_{2}$ concentrations $(\leq 50 \mu \mathrm{M})$ when aconitase is inactivated, glutamate fuels the Krebs cycle and NADH generation is unaltered, (3) at higher $\mathrm{H}_{2} \mathrm{O}_{2}$ concentrations $(\geq 100 \mu \mathrm{M})$ inhibition of $\alpha$-ketoglutarate dehydrogenase limits the amount of $\mathrm{NADH}$ available for the respiratory chain, and (4) increased consumption of NADPH makes a contribution to the $\mathrm{H}_{2} \mathrm{O}_{2}$-induced decrease in the amount of reduced pyridine nucleotides. These results emphasize the importance of $\alpha-\mathrm{KGDH}$ in impaired mitochondrial function under oxidative stress, with implications for neurodegenerative diseases and cell damage induced by ischemia/reperfusion.

Key words: hydrogen peroxide; oxidative stress; mitochondria; Krebs cycle; $\alpha$-ketoglutarate dehydrogenase; aconitase; $N A D H$
It has been recognized in recent years that mitochondria play a crucial role in conditions involving oxidative stress, e.g., in neurodegenerative diseases (Olanow, 1993; Beal, 1996; Gibson et al., 1998a,b), excitotoxicity (Wang and Thayer, 1996; White and Reynolds, 1996), and ischemia/reperfusion (Phillis, 1994; Siesjö et al., 1995; Zhang and Lipton, 1999).

The respiratory chain is a rich source of reactive oxygen species (Boveris et al., 1972; Loschen et al., 1974; Nohl et al., 1981; Cino and Del Maestro, 1989; Dykens, 1994), but mitochondria could also be a vulnerable target of oxidative stress (Hyslop et al., 1988; Zhang et al., 1990). To understand the mechanisms by which reactive oxigen species have a short or long term impact on the functional integrity of cells, it is important to identify specific mitochondrial targets and to characterize processes involved in the oxidative stress-induced mitochondrial damage.

Hydrogen peroxide is a relatively mild means of inducing oxidative stress, because components of the respiratory chain are only marginally influenced (Zhang et al., 1990), and nonspecific peroxidation of membrane lipids is not evoked by this oxidant (Tretter and Adam-Vizi, 1996). The relevance of $\mathrm{H}_{2} \mathrm{O}_{2}$ for modeling oxidative stress is emphasized by the fact that excessive production of $\mathrm{H}_{2} \mathrm{O}_{2}$ is characteristic in aging brain (Sohal et al., 1994; Auerbach and Segal, 1997) and has been demonstrated in the striatum during reperfusion after an hypoxic insult (Hyslop et al., 1995). In addition, generation of $\mathrm{H}_{2} \mathrm{O}_{2}$ has also been suggested to contribute to

Received July 25, 2000; revised Sept. 7, 2000; accepted Sept. 18, 2000.

This work supported by grants from OR52AGO5 Tudomànyos Kutatàsi Alap, EGES2SEGUGTI Tudomanyos Tanacs, Oktatasi Miniszterium, and Magyar Tudomànyos Akademia to V.A.-V. We are indebted to Katalin Takács and Katalin Zölde for excellent technical assistance.

Correspondence should be addressed to Prof. Vera Adam-Vizi, Department of Medical Biochemistry, Semmelweis University of Medicine, Budapest, H-1444, P.O. Box 262, Hungary. E-mail: AV@puskin.sote.hu.

Copyright (C) 2000 Society for Neuroscience $0270-6474 / 00 / 208972-08 \$ 15.00 / 0$ the neuronal damage observed in Parkinson's disease (Schapira, 1994).

Previous studies suggested an impaired mitochondrial function evolving in the early phase of an $\mathrm{H}_{2} \mathrm{O}_{2}$-induced oxidative stress, because there was a decline in the ATP level and ATP/ADP ratio in nerve terminals (Tretter et al., 1997) and a potentiated glutamate-induced loss of mitochondrial membrane potential $(\Delta \Psi \mathrm{m})$ in cultured cortical cells (Scanlon and Reynolds, 1998). Furthermore, we found that $\mathrm{H}_{2} \mathrm{O}_{2}$ decreased the activity of $\alpha$-ketoglutarate dehydrogenase ( $\alpha$-KGDH) in nerve terminals and suggested that $\Delta \Psi \mathrm{m}$ was reduced as a result of an impaired respiratory capacity because of an insufficient amount of NADH generated in the Krebs cycle (Chinopoulos et al., 1999).

The aim of the present work was to address specifically the function of the Krebs cycle, and to identify the enzymes responsible for limiting the availability of NADH to the respiratory chain during an acute exposure to $\mathrm{H}_{2} \mathrm{O}_{2}$-mediated oxidative stress. Studying oxidative stress-induced loss of functions in in situ mitochondria in nerve terminals is relevant in the light of the observation that over the progress of certain neurodegenerative diseases, such as Alzheimer's disease, mitochondrial damage appears to start at nerve terminals (Sumpter et al., 1986; see also Blass and Gibson, 1991). In this preparation a limited capacity of the respiratory chain in the early stage of an $\mathrm{H}_{2} \mathrm{O}_{2}$-induced oxidative stress appeared to be satisfactory under resting conditions, but when combined with other insults (mitochondrial blockers, $\left[\mathrm{Na}^{+}\right]_{\mathrm{i}}$ load) it resulted in a complete functional collapse (Chinopoulos et al., 2000).

We demonstrate here that aconitase is the most sensitive enzyme to $\mathrm{H}_{2} \mathrm{O}_{2}$ in the Krebs cycle; however, inhibition of $\alpha-\mathrm{KGDH}$ by the oxidant limits the amount of NADH available to the respiratory chain. During an acute exposure of nerve terminals to $\mathrm{H}_{2} \mathrm{O}_{2}$, glutamate serves as an alternative metabolite, thus NADH production in the Krebs cycle is maintained. This study, by underlying the 
critical role of $\alpha-\mathrm{KGDH}$ in the impaired mitochondrial function under oxidative stress, may be relevant to neurodegeneration in which a reduced function of this enzyme appears to play a crucial role (Blass and Gibson, 1991; Mizuno et al., 1994; Gibson et al., 1998a).

\section{MATERIALS AND METHODS}

\section{Preparation of synaptosomes}

Isolated nerve terminals (synaptosomes) were prepared from brain cortex of guinea pigs as detailed elsewhere (Chinopoulos et al., 2000). Synaptosomes suspended in $0.32 \mathrm{M}$ sucrose $(\sim 20 \mathrm{mg} / \mathrm{ml}$ of protein) were kept on ice, and aliquots were used for further manipulation. Incubations were carried our in standard medium containing (in mM): $140 \mathrm{NaCl}, 3 \mathrm{KCl}, 2$ $\mathrm{MgCl}_{2}, 2 \mathrm{CaCl}_{2}, 10$ PIPES, $\mathrm{pH} 7.38$, and $10 \mathrm{~mm}$ glucose at $37^{\circ} \mathrm{C}$ as described below.

\section{Steady-state $N A D(P) H$ quantification}

Aliquots of synaptosomes were incubated in the standard medium $(0.5$ $\mathrm{mg} / \mathrm{ml}$ protein). The intrasynaptosomal $\mathrm{NAD}(\mathrm{P}) \mathrm{H}$ level was measured fluorimetrically in the dual emission mode of a PTI Deltascan fluorescence spectrophotometer using $344 \mathrm{~nm}$ excitation wavelength with emission at 460 and $550 \mathrm{~nm}$ (used as a reference) wavelengths. Changes in NAD $(\mathrm{P}) \mathrm{H}$ concentration were quantified using a calibration curve of externally added NADH $(1-3 \mathrm{nmol})$.

\section{Determination of activities of TCA cycle enzymes}

Synaptosomes were incubated in standard medium $(0.5 \mathrm{mg} / \mathrm{ml}$ protein $)$ in the presence or absence of $\mathrm{H}_{2} \mathrm{O}_{2}$, then aliquots were transferred into different media for enzyme assays.

Citrate synthase. Citrate synthase was measured as described by Srere (1969). Aliquots of synaptosomes $(50 \mu \mathrm{g}$ protein) were added to a medium containing $0.1 \mathrm{~mm}$ acetyl-CoA, $0.2 \mathrm{~mm}$ dithionitrobenzoic acid, $0.2 \%$ Triton X-100 (v/v), $100 \mathrm{~mm}$ Tris-HCl, $\mathrm{pH}$ 8.0. Changes in the absorbance at $412 \mathrm{~nm}$ were monitored in a GBC UV/VIS 920 spectrophotometer. After a stable baseline signal was obtained, the enzyme reaction was started with addition of $0.2 \mathrm{~mm}$ oxaloacetate.

Aconitase. Aconitase was assayed as described by Hausladen and Fridovich (1996). Synaptosomal aliquots (100 $\mu \mathrm{g}$ protein) were transferred to a medium containing $50 \mathrm{~mm}$ Tris- $\mathrm{HCl}, 0.6 \mathrm{mM} \mathrm{MnCl}_{2}, 30 \mathrm{~mm}$ sodium citrate, $0.2 \%$ Triton $\mathrm{X}-100,2 \mathrm{U} / \mathrm{ml}$ isocitrate dehydrogenase (NADP ${ }^{+}$. dependent), and catalase $(1 \mathrm{U} / \mathrm{ml})$ at $37^{\circ} \mathrm{C}, \mathrm{pH}$ 7.4. The reaction was initiated by addition of $0.2 \mathrm{mM} \mathrm{NADP}^{+}$. Fluorescence was monitored at $340 \mathrm{~nm}$ with a GBC UV/VIS 920 spectrophotometer. Results were calculated with $\mathrm{E}_{\mathrm{m}}=6.22$ for NADH.

$\alpha$-Ketoglutarate dehydrogenase. $\alpha$-Ketoglutarate dehydrogenase was assayed essentially as described by Lai and Cooper (1986). Aliquots (75 $\mu \mathrm{g}$ protein) were added to a medium containing $0.2 \mathrm{~mm}$ thiamine pyrophosphate, $2 \mathrm{~mm} \mathrm{NAD}^{+}, 1 \mathrm{~mm} \mathrm{MgCl}_{2}, 0.4 \mathrm{~mm}$ ADP, $10 \mu \mathrm{M}$ rotenone, $0.1 \%$ (v/v) Triton X-100, $50 \mathrm{~mm}$ potassium phosphate buffer, $\mathrm{pH} 7.4$, and $0.2 \mathrm{~mm}$ EGTA. The reaction was initiated by addition of $0.12 \mathrm{~mm}$ HS-CoA and 1 mM $\alpha$-ketoglutarate. Dithiothreitol was omitted from the assay medium to prevent a possible reactivation of oxidative stress-sensitive $\mathrm{SH}$ groups of the enzyme. NADH fluorescence was followed as described above.

Succinate dehydrogenase. This was assayed as described by Tan et al. (1993). Synaptosomal protein $(50 \mu \mathrm{g})$ was transferred to an assay medium containing $60 \mu \mathrm{M}$ 2,3-dimethoxy-5-methyl-6-decyl-1,4-benzo-quinone, 50 $\mu \mathrm{M}$ 2,6-dichlorophenolindophenol (terminal electron acceptor), $2 \mu \mathrm{M}$ rotenone, $5 \mathrm{~mm} \mathrm{KCN}, 1 \mathrm{~mm}$ EGTA, $0.2 \%$ Triton $\mathrm{X}-100(\mathrm{v} / \mathrm{v}), 250 \mathrm{~mm}$

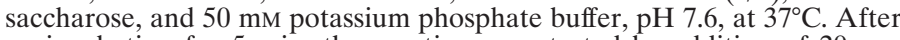
preincubation for $5 \mathrm{~min}$, the reaction was started by addition of $20 \mathrm{~mm}$ succinate. Absorbance changes were recorded at $600 \mathrm{~nm}$ in a GBC UV/ VIS 920 recording spectrophotometer. Enzyme activities were calculated with $\mathrm{E}_{\mathrm{mM}}=19.1$ for 2,6-dichlorophenolindophenol.

Malate dehydrogenase. Malate dehydrogenase was measured as described by Kitto (1969). Aliquots (20 $\mu \mathrm{g}$ protein) were transferred into a medium containing $10 \mu \mathrm{M}$ rotenone, $0.2 \%$ Triton X-100, $0.15 \mathrm{~mm} \mathrm{NADH}$, and 100 mM potassium phosphate buffer, $\mathrm{pH} 7.4$, at $37^{\circ} \mathrm{C}$. The reaction was started by addition of $0.33 \mathrm{~mm}$ oxaloacetate. Absorbance was monitored as described above.

\section{Determination of $N A D P^{+}+N A D P H$ pool}

An assay described by Nisselbaum and Green (1969) was used for NADP $+\mathrm{NAD}(\mathrm{P}) \mathrm{H}$ measurements. Synaptosomes $(0.5 \mathrm{mg} / \mathrm{ml})$ were preincubated in standard medium for 10 min, then $\mathrm{H}_{2} \mathrm{O}_{2}$ was added. Samples were treated as described (Klingenberg, 1974). Protein samples $(50 \mu \mathrm{g})$ were added to a medium containing $3.5 \mathrm{U} / \mathrm{ml}$ glucose 6-phosphate dehydrogenase, $0.5 \mathrm{~mm}$ thiazolyl blue (MTT), $0.2 \mathrm{~mm}$ phenazine ethosulfate (PES), $50 \mathrm{~mm}$ Tris- $\mathrm{HCl}$, and $0.5 \mathrm{~mm}$ EDTA, $\mathrm{pH}$ 7.4. Changes in the absorbance were followed at $570 \mathrm{~nm}$ in a GBC UV/VIS 920 double-beam spectrophotometer at $37^{\circ} \mathrm{C}$. After a stable baseline was obtained, the reaction was started by addition of $5 \mathrm{~mm}$ glucose-6-phosphate. External and internal calibrations with known amounts of $\mathrm{NADP}^{+}$were used for quantification of results.

\section{Determination of $\mathrm{NAD}^{+}+\mathrm{NADH}$ pool}

$\mathrm{NAD}^{+}+\mathrm{NADH}$ content in synaptosomes was measured as described (Bernofsky and Swan, 1973), using a sampling method (Klingenberg, 1974). Samples from synaptosomes $(20 \mu \mathrm{g}$ protein) were transferred to an assay medium containing $0.2 \mathrm{mg}$ alcohol dehydrogenase (Sigma A3263, Sigma, St. Louis, MO), 0.5 mm MTT, 0.2 mM PES, $0.6 \mathrm{M}$ ethanol, $50 \mathrm{~mm}$ Tris- $\mathrm{HCl}$, and $0.5 \mathrm{~mm}$ EDTA, $\mathrm{pH} 7.8$, and absorbance was followed at 570 $\mathrm{nm}\left(30^{\circ} \mathrm{C}\right)$ in a GBC UV/VIS 920 spectrophotometer. External and internal calibrations with known amounts of $\mathrm{NAD}^{+}$were used for quantification of results.

\section{Assay for glutathione reductase activity}

For glutathione reductase assay (Carlberg and Mannervik, 1985), aliquots of synaptosomes $(0.2 \mathrm{mg}$ protein) were incubated in a medium containing $0.2 \%$ Triton X-100, $0.1 \mathrm{~mm}$ NADPH, $100 \mathrm{~mm}$ potassum phosphate, and 1 mM EGTA, pH 7.4, at $37^{\circ} \mathrm{C}$. After a stable baseline was obtained, reaction was started by addition of $1 \mathrm{~mm}$ oxidized glutathion. NADPH absorbance was measured as described above.

\section{Determination of glutamate content of synaptosomes}

The method described by Hinman and Blass (1981) was adapted to measure the amount of glutamate. Aliquots $(200 \mu \mathrm{l})$ of synaptosomes incubated in standard medium $(0.5 \mathrm{mg} / \mathrm{ml})$ were added to an assay medium containing glutamic dehydrogenase (Sigma G7882) $7.5 \mathrm{U}$ per assay, $1 \mathrm{~mm}$ $\mathrm{NADP}^{+}, 1 \mathrm{mM} \mathrm{MgCl}, 0.6 \mathrm{mM} p$-iodonitrotetrazolium violet, $6.5 \mu \mathrm{M}$ phenazine methosulfate, 2 mM ADP, $0.1 \%$ Triton X-100, 0.2 mM EGTA, and $50 \mathrm{~mm}$ Tris- $\mathrm{HCl}$ buffer, $\mathrm{pH} 7.8$. Changes in the absorbance were followed at $500 \mathrm{~nm}\left(30^{\circ} \mathrm{C}\right)$ in a GBC UV/VIS 920 spectrophotometer. Internal calibrations with known amounts of glutamate were used for quantification of results.

\section{Statistics}

Statistical differences were evaluated with ANOVA (Sigmastat) for multiple comparisons.

\section{Materials}

Standard laboratory chemicals were obtained from Sigma (St. Louis, MO). Special peroxide- and carbonyl-free Triton X-100 (Sigma) was used throughout the experiments for disrupting synaptosomal membranes without further oxidative damage. BCNU was a gift from Laszlo Kopper (Department of Pathology, Semmelweis University, Budapest).

\section{RESULTS}

\section{Effect of $\mathrm{H}_{2} \mathrm{O}_{2}$ on the activity of enzymes in the Krebs cycle}

The activity of enzymes in the Krebs cycle was investigated in the presence of $\mathrm{H}_{2} \mathrm{O}_{2}$, with a particular focus on enzymes working with $\mathrm{NAD}^{+}$as a cofactor. Synthesis of citrate is generally regarded as the "first" reaction of the cycle catalyzed by citrate synthase, which proved to be insensitive to $\mathrm{H}_{2} \mathrm{O}_{2}$ (Table 1). By contrast, aconitase, which has been reported previously to be sensitive to inhibition by superoxide anion (Patel et al., 1996; Gardner et al., 1997) and nitric oxide and peroxynitrate (Andersson et al., 1998), was inhibited by $\mathrm{H}_{2} \mathrm{O}_{2}$ in a concentration-dependent manner (Fig. 1). The activity of aconitase was significantly reduced to $75.5 \pm 4.9 \%$ of control $(n=8, p<0.05)$ after 5 min incubation with $5 \mu \mathrm{M} \mathrm{H}_{2} \mathrm{O}_{2}$, nearly completely inhibited (to $13.6 \pm 1.27 \%$ of control) by $25 \mu \mathrm{M} \mathrm{H}_{2} \mathrm{O}_{2}$, and completely inactivated by $50 \mu \mathrm{M} \mathrm{H}_{2} \mathrm{O}_{2}$.

Isocitrate is converted to $\alpha$-ketoglutarate by $\mathrm{NAD}^{+}$-dependent isocitrate dehydrogenase, which in our previous study was not inhibited by $\mathrm{H}_{2} \mathrm{O}_{2}$ applied in 100 or $500 \mu \mathrm{M}$ concentrations (Chinopoulos et al., 1999).

$\alpha$-Ketoglutarate dehydrogenase is the second dehydrogenase in the cycle that generates NADH. As demonstrated in Figure $2 a$, the activity of $\alpha-\mathrm{KGDH}$ was inhibited by $\mathrm{H}_{2} \mathrm{O}_{2}$ in proportion to the concentration of the oxidant. Statistically significant reduction of the enzyme was observed at 50 and $100 \mu \mathrm{M} \mathrm{H} \mathrm{H}_{2} \mathrm{O}_{2}$ after incubation for 10 or $5 \mathrm{~min}$, respectively, but at $500 \mu \mathrm{M}$, incubation for $2.5 \mathrm{~min}$ was sufficient for the enzyme to be significantly inhibited (Fig. $2 b$ ). It should be noted that in comparison with the effects on aconitase, higher concentrations of $\mathrm{H}_{2} \mathrm{O}_{2}$ were required for inhibiting $\alpha-\mathrm{KGDH}$, and the enzyme was not completely inactivated even at $500 \mu \mathrm{M} \mathrm{H} \mathrm{H}_{2} \mathrm{O}_{2}$ present for $10 \mathrm{~min}(38.3 \pm 5.6 \%$ of control).

Succinate dehydrogenase present in rat liver mitochondria was reported to be vulnerable to a strong lipid peroxidative insult induced by ADP/Fe (Tretter et al., 1987), but in heart submito- 
Table 1. The effect of $\mathrm{H}_{2} \mathrm{O}_{2}$ on the activity of citrate synthase, succinate dehydrogenase, and malate dehydrogenase

\begin{tabular}{lccccc} 
& \multicolumn{3}{l}{ Activity $(\%$ of control $)$} & \\
\cline { 2 - 3 } & $100 \mu \mathrm{M} \mathrm{H}_{2} \mathrm{O}_{2}$ & & & $500 \mu \mathrm{M} \mathrm{H}_{2} \mathrm{O}_{2}$ & \\
\cline { 2 - 3 } \cline { 5 - 6 } & $5 \mathrm{~min}$ & & & $5 \mathrm{~min}$ & $10 \mathrm{~min}$ \\
\hline Citrate synthase & $\mathrm{ND}$ & & $98.2 \pm 1.8$ & $98.3 \pm 1.2$ \\
Succinate dehydrogenase & $88 \pm 1.12^{a}$ & $76 \pm 2.9^{a}$ & & $74 \pm 4.6^{a}$ & $70.8 \pm 3.7^{a}$ \\
Malate dehydrogenase & $101.2 \pm 1.8$ & $104 \pm 1.8$ & & $97.4 \pm 2.3$ & $105 \pm 4.1$ \\
\hline
\end{tabular}

Nerve terminals were incubated with $\mathrm{H}_{2} \mathrm{O}_{2}$ as indicated, then enzyme activities were determined in assay media containing Triton X-100 to permeabilize the plasma membrane as described in Materials and Methods. Results are expressed as percentage activity of the corresponding controls measured without $\mathrm{H}_{2} \mathrm{O}_{2}$ treatment. The following activities were taken as 100\%: (1) citrate synthase, $778 \pm 70 \mathrm{nmol} \cdot \mathrm{min}^{-1} \cdot \mathrm{mg}^{-1}$ protein $(n=4)$; (2) succinate dehydrogenase, $30 \pm 0.69$ $\mathrm{nmol} \cdot \mathrm{min}^{-1} \cdot \mathrm{mg}^{-1}$ protein $(n=4)$; and (3) malate dehydrogenase, $12 \pm 0.26 \mu \mathrm{mol} \cdot \mathrm{min}^{-1} \cdot \mathrm{mg}^{-1} \operatorname{protein}(n=4)$. Results are the average of four independent determinations \pm SEM. ND, Not determined.

${ }^{a}$ Significantly different from the corresponding control.

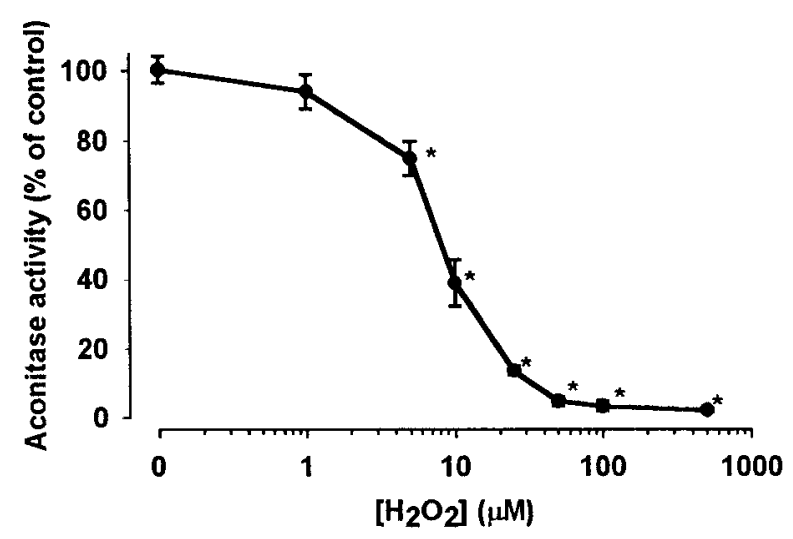

Figure 1. Inhibition of aconitase by $\mathrm{H}_{2} \mathrm{O}_{2}$. Nerve terminals were incubated in the absence (control) or presence of different concentrations of $\mathrm{H}_{2} \mathrm{O}_{2}$. Aconitase activity was measured after incubation with $\mathrm{H}_{2} \mathrm{O}_{2}$ for 5 min. In the control samples the activity of aconitase was 86.4 33.4 $\mathrm{nmol} \cdot \mathrm{min}^{-1} \cdot \mathrm{mg}^{-1}$ protein taken as $100 \%$. Enzyme activities are expressed as percentage of control. Data are the average \pm SEM of eight determinations made in four independent experiments. *Significant compared with the control, $p<0.05$.
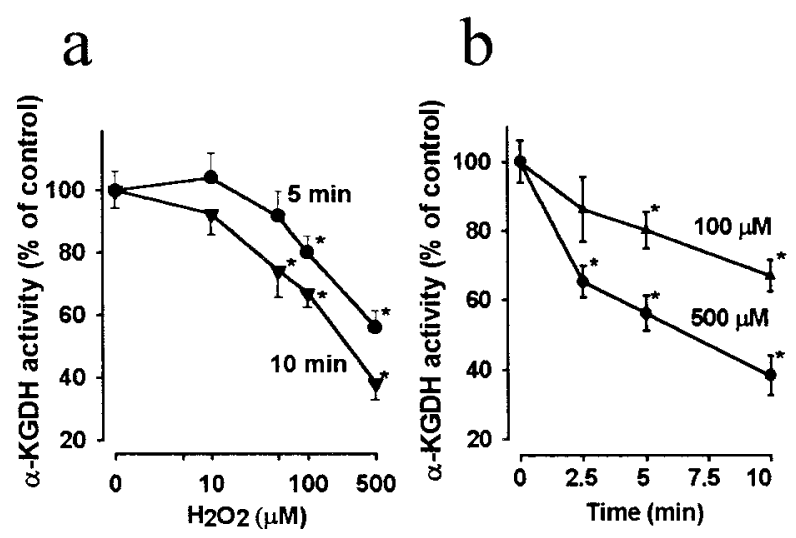

Figure 2. Inhibition of $\alpha$-ketoglutarate dehydrogenase by $\mathrm{H}_{2} \mathrm{O}_{2}$. Nerve terminals were incubated in the absence (control) or presence of different concentrations of $\mathrm{H}_{2} \mathrm{O}_{2}$ for 5 or 10 min $(a)$, or with 100 and $500 \mu \mathrm{M} \mathrm{H}_{2} \mathrm{O}_{2}$, respectively, for different lengths of time $(b)$. In control samples the activity of $\alpha$-KGDH was $14.2 \pm 1.2 \mathrm{nmol} \cdot \mathrm{min}^{-1} \cdot \mathrm{mg}^{-1}$ taken as $100 \%$. Data are the average \pm SEM of eight determinations made in three independent experiments. ${ }^{*}$ Significant compared with the control, $p<0.05$.

chondrial particles $\mathrm{H}_{2} \mathrm{O}_{2}$ had no detectable effect on the enzyme (Zhang et al., 1990). Table 1 shows that succinate dehydrogenase in synaptosomes was sensitive to $\mathrm{H}_{2} \mathrm{O}_{2}$. However, it is important to note that $70.8 \pm 3.7 \%$ of the enzyme activity was still maintained after incubation with $500 \mu \mathrm{M} \mathrm{H}_{2} \mathrm{O}_{2}$ for $10 \mathrm{~min}$, whereas the activity $\alpha$-KGDH was decreased to $38.2 \pm 5.6 \%$ of control under the same condition (Fig. $2 b$ ). These results show that the extent of inhibition of this enzyme is smaller than that of $\alpha-\mathrm{KGDH}$ at identical concentrations of the oxidant.

Malate dehydrogenase, which has a relatively high activity [see also Yudkoff et al. (1994)] was insensitive to $\mathrm{H}_{2} \mathrm{O}_{2}$-mediated oxidative stress (Table 1 ).

These results indicate that three enzymes are inhibited in the Krebs cycle during an acute exposure of nerve terminals to $\mathrm{H}_{2} \mathrm{O}_{2}$ : (1) aconitase, which is the most sensitive to the oxidant, (2) $\alpha$-KGDH, the only enzyme inhibited by $\mathrm{H}_{2} \mathrm{O}_{2}$ that contributes directly to the formation of NADH, and (3) succinate dehydrogenase, which appears to be a less vulnerable target to $\mathrm{H}_{2} \mathrm{O}_{2}$ than is $\alpha-\mathrm{KGDH}$.

\section{Changes in the NAD(P)H fluorescence caused by to $\mathrm{H}_{2} \mathrm{O}_{2}$}

To investigate whether $\mathrm{H}_{2} \mathrm{O}_{2}$-mediated inhibition of enzymes in the Krebs cycle, particularly that of $\alpha \mathrm{KGDH}$, could limit the amount of NADH available for the respiratory chain, we monitored fluorescence changes at $344 \mathrm{~nm}$ in nerve terminals. Because fluorescence of both NADH and NADPH is measured by this method, in this paper the fluorescence signals obtained are referred to as changes in the NAD $(\mathrm{P}) \mathrm{H}$ level.

We have reported recently that oxidative stress induced by 100 or $500 \mu \mathrm{M} \mathrm{H} \mathrm{H}_{2} \mathrm{O}_{2}$ decreased the basal fluorescence signal, indicating a decrease in the steady-state $\mathrm{NAD}(\mathrm{P}) \mathrm{H}$ level (Chinopoulos et al., 1999) (Fig. 3, inset, trace b). Here the effect of $\mathrm{H}_{2} \mathrm{O}_{2}$ was investigated further by recording changes in the NAD $(\mathrm{P}) \mathrm{H}$ level induced by rotenone, inhibitor of complex I (NADH/ubiquinone oxidoreductase) in the respiratory chain. Addition of rotenone $(2 \mu \mathrm{M})$ induced an abrupt increase in the fluorescence of NAD(P)H (Fig. 3 , inset, trace a, $\triangle N A D(P) H$ ), this signal being proportional to the amount of NADH available for the respiratory chain. We found that monitoring the rotenone-induced fluorescence signal, rather than the basal fluorescence, enabled us to obtain more consistent results and better resolution of the oxidant-induced changes in the $\mathrm{NAD}(\mathrm{P}) \mathrm{H}$ level. Figure 3 (inset, trace $b$ ) shows a typical experiment in which exposure to $\mathrm{H}_{2} \mathrm{O}_{2}$ for 5 min reduced the rotenone-induced fluorescence signal, indicating a decrease in the NAD $(\mathrm{P}) \mathrm{H}$ level. The effect of $\mathrm{H}_{2} \mathrm{O}_{2}$ in both 100 and $500 \mu \mathrm{M}$ concentrations (Fig. 3) was significant after incubation for $2.5 \mathrm{~min}(72 \pm 8.1 \%$ and $47 \pm$ $4.9 \%$ of control, respectively) and was maximal after $7.5 \mathrm{~min}$ $(46.7 \pm 1.5 \%$ and $31.8 \pm 2.3 \%$ of control, respectively).

The decrease in $\triangle \mathrm{NAD}(\mathrm{P}) \mathrm{H}$ was proportional to the concentration of the oxidant (Fig. 4, curve a). After incubation with $500 \mu \mathrm{M}$ $\mathrm{H}_{2} \mathrm{O}_{2}$ for $5 \mathrm{~min}$, the rotenone-induced $\mathrm{NAD}(\mathrm{P}) \mathrm{H}$ signal decreased to $34 \pm 0.4 \%$ as compared with control, but the effect of $\mathrm{H}_{2} \mathrm{O}_{2}$ at $15 \mu \mathrm{M}$ was already significant $(83 \pm 3.6 \%)$. 


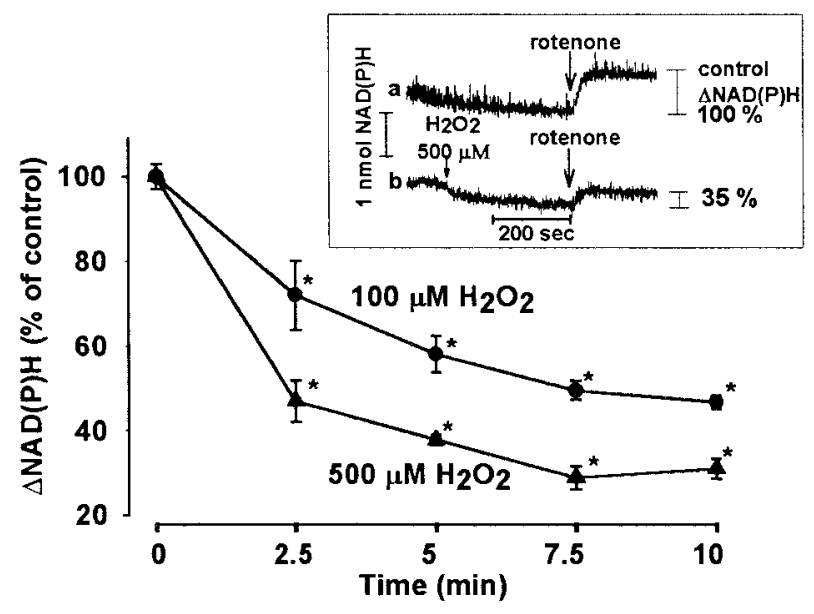

Figure 3. Decrease in the $\mathrm{NAD}(\mathrm{P}) \mathrm{H}$ level by $\mathrm{H}_{2} \mathrm{O}_{2}$. Fluorescence of $\mathrm{NAD}(\mathrm{P}) \mathrm{H}$ was monitored in synaptosomes $(0.5 \mathrm{mg} / \mathrm{ml}$ protein $)$ incubated in standard medium in the presence or absence of $\mathrm{H}_{2} \mathrm{O}_{2}$. Five minutes after application of $\mathrm{H}_{2} \mathrm{O}_{2}$, rotenone $(2 \mu \mathrm{M})$ was added. To calculate $\Delta \mathrm{NAD}(\mathrm{P}) \mathrm{H}$, the fluorescence measured $10 \mathrm{sec}$ before addition of rotenone was subtracted from that obtained $100 \mathrm{sec}$ after rotenone application. $\triangle \mathrm{NAD}(\mathrm{P}) \mathrm{H}$ representing the effect of rotenone in the absence of $\mathrm{H}_{2} \mathrm{O}_{2}$ (inset, trace a) was taken as control $(100 \%)$. The rotenone-induced NAD(P)H signals obtained in the presence of 100 or $500 \mu \mathrm{M} \mathrm{H}_{2} \mathrm{O}_{2}$ are shown (\% of control) as a function of time; $100 \%$ represents $1.18 \pm 0.04 \mathrm{nmol} \mathrm{NAD}(\mathrm{P}) \mathrm{H}$, calibrated with added amounts of NADPH. Results are mean \pm SEM of five determinations from three independent experiments. *Significant compared with the control, $p<0.05$.

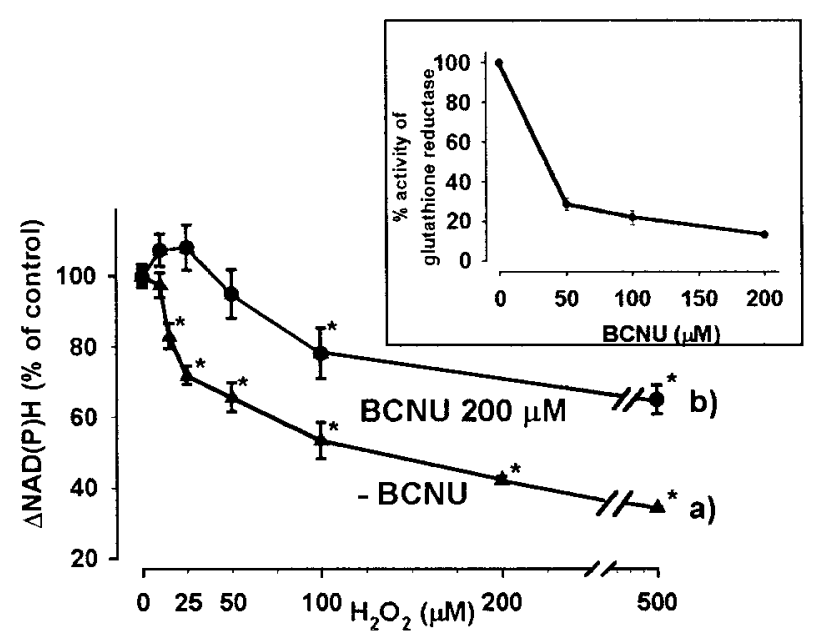

Figure 4. Decrease in the $\mathrm{NAD}(\mathrm{P}) \mathrm{H}$ level by $\mathrm{H}_{2} \mathrm{O}_{2}$ in the absence or presence of $\mathrm{BCNU}$, inhibitor of glutathione reductase. Synaptosomes (6 $\mathrm{mg} / \mathrm{ml}$ ) were incubated in the presence $(b)$ or absence $(a)$ of BCNU for 30 $\min$ at $37^{\circ} \mathrm{C}$, then cooled to $0^{\circ} \mathrm{C}$. Aliquots $(1 \mathrm{mg}$ protein $)$ were incubated in standard medium $(0.5 \mathrm{mg} / \mathrm{ml})$, and NAD $(\mathrm{P}) \mathrm{H}$ fluorescence was measured as described for Figure 3 , in the presence of different concentrations of $\mathrm{H}_{2} \mathrm{O}_{2}$ for 5 min. Results are expressed as mean \pm SEM of three independent experiments; $100 \%$ represents $1.17 \pm 0.06 \mathrm{nmol} \mathrm{NAD}(\mathrm{P}) \mathrm{H}$. Inset shows the activity of glutathione reductase measured after incubation with different concentrations of BCNU for $30 \mathrm{~min}$. The activity of glutathione reductase in control samples $(100 \%)$ was $28 \pm 0.56 \mathrm{nmol} \cdot \mathrm{min}^{-1} \cdot \mathrm{mg}^{-1}$ protein. Data are mean \pm SEM of five determinations, $p<0.05$.

\section{The effect of $\mathrm{H}_{2} \mathrm{O}_{2}$ on the NAD(P)H level in glucose-free medium}

$\mathrm{H}_{2} \mathrm{O}_{2}$ has been reported to inhibit gliceraldehyde-3-phosphatedehydrogenase (Hyslop et al., 1988; Janero et al., 1993); thus we investigated whether a reduced NADH production in the glycolysis could contribute to the results shown in Figures 3 and 4. For this, the effect of $\mathrm{H}_{2} \mathrm{O}_{2}$ on $\Delta \mathrm{NAD}(\mathrm{P}) \mathrm{H}$ was investigated in the absence of glucose, using the experimental protocol shown in Figure 3 (inset). In the absence of glucose, glycolysis is unable to proceed; thus NADH is generated mainly in the Krebs cycle from alterna- tive substrates. Synaptosomes were preincubated for $20 \mathrm{~min}$ in glucose-free standard medium in the presence of $5 \mathrm{~mm}$ 2-deoxyglucose (preventing glycolysis driven by a possible glycogen store), and the rotenone-induced elevation in the NAD $(\mathrm{P}) \mathrm{H}$ fluorescence was investigated after pretreatment with various concentrations of $\mathrm{H}_{2} \mathrm{O}_{2}$ for 5 min. In Table 2 the results are compared with those obtained in glucose-containing medium, and this shows that the effect of $\mathrm{H}_{2} \mathrm{O}_{2}$ on the rotenone-induced $\mathrm{NAD}(\mathrm{P}) \mathrm{H}$ signal was quantitatively similar under these conditions. The presence or absence of 2-deoxyglucose made no difference in the results (data not shown). These findings indicate that nerve terminals are able to generate NADH in the absence of glucose, and this NADH generation is sensitive to $\mathrm{H}_{2} \mathrm{O}_{2}$-induced oxidative stress.

\section{Pyridine nucleotide pool is unaltered by $\mathrm{H}_{2} \mathrm{O}_{2}$}

Given the observation that treatment of the $\mathrm{P}_{388 \mathrm{D}_{1}}$ cell line (Hyslop et al., 1988) and cardiomyocytes (Janero et al., 1993) with $\mathrm{H}_{2} \mathrm{O}_{2}$ caused a loss of pyridine nucleotides, it was of interest to determine whether this occurs in nerve terminals contributing to the $\mathrm{H}_{2} \mathrm{O}_{2}$-induced decrease in the rotenone-induced NAD $(\mathrm{P}) \mathrm{H}$ fluorescence. Thus, we measured the total $\mathrm{NAD}^{+} / \mathrm{NADH}$ and $\mathrm{NADP}^{+} / \mathrm{NADPH}$ pool in the absence and presence of 100 or 500 $\mu \mathrm{M} \mathrm{H}_{2} \mathrm{O}_{2}$. Table 3 shows that the total pyridine nucleotide pool remained unchanged in the presence of $\mathrm{H}_{2} \mathrm{O}_{2}$; the small decrease observed in the $\mathrm{NAD}^{+} / \mathrm{NADH}$ content at $500 \mu \mathrm{M} \mathrm{H}_{2} \mathrm{O}_{2}$ was statistically insignificant.

\section{Inhibition of glutathione reductase partly prevents the $\mathrm{H}_{2} \mathrm{O}_{2}$-induced decrease in the $\mathrm{NAD}(\mathrm{P}) \mathrm{H}$ signal}

In addition to catalase, glutathione peroxidase plays an important role in the brain in the elimination of $\mathrm{H}_{2} \mathrm{O}_{2}$ (Desagher et al., 1996; Dringen et al., 1999). Hence an increased consumption of NADPH by glutathione reductase in the presence of $\mathrm{H}_{2} \mathrm{O}_{2}$ could contribute to the decrease in the rotenone-induced NAD $(\mathrm{P}) \mathrm{H}$ signal. To test this possibility, glutathione reductase was inhibited by BCNU, which carbamoylates thiol groups of the enzyme (Becker and Schirmer, 1995), and changes in the rotenone-induced NAD $(\mathrm{P}) \mathrm{H}$ fluorescence caused by $\mathrm{H}_{2} \mathrm{O}_{2}$ were investigated. BCNU at $200 \mu \mathrm{M}$ concentration was used in these experiments, and it almost completely inhibited glutathione reductase $(86.7 \pm 1.4 \%$ inhibition $)$ (Fig. 4, inset) without influencing the resting $\mathrm{NAD}(\mathrm{P}) \mathrm{H}$ level or the rotenone-induced $\mathrm{NAD}(\mathrm{P}) \mathrm{H}$ signal (data not shown). At higher concentrations of $\mathrm{BCNU}$, the control and the rotenone-induced fluorescent signals were also decreased (data not shown), probably reflecting an inhibition of other enzymes, most notably lipoamide dehydrogenase (Ahmad and Frischer, 1985). In the presence of BCNU, the effect of small concentrations of $\mathrm{H}_{2} \mathrm{O}_{2}(5-50 \mu \mathrm{M})$ on the rotenone-induced $\mathrm{NAD}(\mathrm{P}) \mathrm{H}$ signal was abolished (Fig. 4, curve $b)$. The effect of $\mathrm{H}_{2} \mathrm{O}_{2}$ at higher concentrations was also reduced after pretreatment with $\mathrm{BCNU}$; however, the decrease in the rotenone-induced $\mathrm{NAD}(\mathrm{P}) \mathrm{H}$ signal remained significant in the presence of both $100 \mu \mathrm{M}(21.2 \pm 8.4 \%)$ and $500 \mu \mathrm{M} \mathrm{H}_{2} \mathrm{O}_{2}(35.1 \pm$ $4.2 \%$ ) (Fig. 4, trace $b$ ).

These experiments indicate that consumption of NADPH via the glutathione reductase/peroxidase system accounts for the decreased rotenone-induced $\mathrm{NAD}(\mathrm{P}) \mathrm{H}$ signal in the presence of small concentrations of $\mathrm{H}_{2} \mathrm{O}_{2}(<50 \mu \mathrm{M})$ and also contributes to that observed at higher concentrations of the oxidant. Therefore, the decrease in the NAD $(\mathrm{P}) \mathrm{H}$ fluorescence induced by $\mathrm{H}_{2} \mathrm{O}_{2}$ at 100 or $500 \mu \mathrm{M}$ concentration, which was observed in the presence of $\mathrm{BCNU}$, could be taken primarily as a reflection of a decrease in the $\mathrm{NADH}$ level, unrelated to consumption of NADPH caused by elimination of the oxidant.

We also tried to block glutathione peroxidase by mercaptosuccinate, but the activity of glutathione peroxidase was unaltered after incubation with $10 \mathrm{~mm}$ mercaptosuccinate for $60 \mathrm{~min}$ at $37^{\circ} \mathrm{C}$. This shows that even the longest incubation period ( $\sim 60 \mathrm{~min}$ ) tolerated by synaptosomes without disturbance in integrity was not sufficient for the drug to gain access to the interior of nerve terminals. 
Table 2. Comparison of the effect of $\mathrm{H}_{2} \mathrm{O}_{2}$ on the rotenone-induced NAD(P)H signal in the presence or absence of glucose

\begin{tabular}{lllll}
\multicolumn{5}{l}{$\Delta$ NAD $(\mathrm{P}) \mathrm{H}$ nmol/mg protein } \\
\cline { 2 - 5 } & Control & $25 \mu \mathrm{M} \mathrm{H} \mathrm{H}_{2}$ & $100 \mu \mathrm{M} \mathrm{H}_{2} \mathrm{O}_{2}$ & $500 \mu \mathrm{M} \mathrm{H}_{2} \mathrm{O}_{2}$ \\
\hline+ Glucose & $1.054 \pm 0.14$ & $0.840 \pm 0.13^{*}$ & $0.544 \pm 0.08^{*}$ & $0.518 \pm 0.07^{*}$ \\
- Glucose & $1.285 \pm 0.17$ & $0.850 \pm 0.17^{*}$ & $0.567 \pm 0.09^{*}$ & $0.418 \pm 0.06^{*}$
\end{tabular}

Synaptosomes were incubated with $\mathrm{H}_{2} \mathrm{O}_{2}$ for 5 min, then rotenone $(2 \mu \mathrm{M})$ was added, and the increase in the NAD(P)H signal $[\triangle \mathrm{NAD}(\mathrm{P}) \mathrm{H}]$ was measured as shown in Figure 3 , inset. Data are mean $\pm \mathrm{SEM}$ of three independent experiments. Values obtained in samples containing $\mathrm{H}_{2} \mathrm{O}_{2}$ are significantly different $(*)$ from the corresponding controls. Differences between values obtained at a given $\mathrm{H}_{2} \mathrm{O}_{2}$ concentration in glucose-containing or glucose-free medium are not statistically different.

Table 3. The effect of $\mathrm{H}_{2} \mathrm{O}_{2}$ on the total pyridine nucleotide pool

\begin{tabular}{|c|c|c|c|c|c|c|}
\hline & \multicolumn{3}{|c|}{$\mathrm{NAD}^{+} / \mathrm{NADH}(\mathrm{pmol} / \mathrm{mg}$ protein $)$} & \multicolumn{3}{|c|}{$\mathrm{NADP}^{+} / \mathrm{NADPH}(\mathrm{pmol} / \mathrm{mg}$ protein $)$} \\
\hline & $0 \mathrm{~min}$ & $5 \min$ & $10 \mathrm{~min}$ & $0 \mathrm{~min}$ & $5 \mathrm{~min}$ & $10 \mathrm{~min}$ \\
\hline Control & $3381 \pm 174$ & $3509 \pm 370$ & $3357 \pm 570$ & $359 \pm 55$ & $387 \pm 42$ & $351 \pm 62$ \\
\hline $100 \mu \mathrm{M} \mathrm{H} \mathrm{H}_{2} \mathrm{O}_{2}$ & ND & $3199 \pm 225$ & $3277 \pm 381$ & ND & $433 \pm 86$ & $403 \pm 62$ \\
\hline $500 \mu \mathrm{M} \mathrm{H} \mathrm{H}_{2} \mathrm{O}_{2}$ & ND & $3016 \pm 410$ & $2852 \pm 425$ & ND & $380 \pm 49$ & $349 \pm 54$ \\
\hline
\end{tabular}

Synaptosomes $\left(0.5 \mathrm{mg} / \mathrm{ml}\right.$ protein) were incubated in standard medium with or without $\mathrm{H}_{2} \mathrm{O}_{2}$ as indicated, and the content of pyridine nucleotides was measured as described in Materials and Methods. Results are given as mean \pm SEM of four independent experiments. ND, Not determined. The content of pyridine nucleotides in $\mathrm{H}_{2} \mathrm{O}_{2}$-treated samples is not significantly different from the corresponding controls.

\section{Correlation between inhibition of $\alpha$-KGDH and decrease in $\mathrm{NAD}(\mathrm{P}) \mathrm{H}$ level induced by $\mathrm{H}_{2} \mathrm{O}_{2}$}

To establish which enzyme(s) could limit NADH production during $\mathrm{H}_{2} \mathrm{O}_{2}$-induced oxidative stress, the relationship between the decrease in the rotenone-induced $\mathrm{NAD}(\mathrm{P}) \mathrm{H}$ signal and the activity of $\alpha-\mathrm{KGDH}$ and aconitase was analyzed. Only data obtained in the presence of BCNU (Fig. 4, curve b) were considered, because in these, fluorescence changes attributable to an increased NADPH consumption by glutathione reductase are not involved. Inhibition of succinate dehydrogenase was not considered, because in nerve terminals, reactions in the TCA cycle between succinate and oxaloacetate operate at a higher rate than does $\alpha$-KGDH (Yudkoff et al., 1994); thus it is unlikely that succinate dehydrogenase could limit the flux in the TCA cycle under conditions in which $\alpha-\mathrm{KGDH}$ is substantially inhibited. A lack of correlation between the activity of succinate dehydrogenase and the flux through the cycle has been reported in rat heart (Cooney et al., 1981). Aconitase is also not a rate-limiting enzyme, but because it is very sensitive to $\mathrm{H}_{2} \mathrm{O}_{2}$ and at higher oxidant concentrations $(50-500 \mu \mathrm{M})$ is inactivated completely, we studied the possible contribution of aconitase to the limitation of NADH production in the TCA cycle. Figure 5 shows decreases in the rotenone-induced $\mathrm{NAD}(\mathrm{P}) \mathrm{H}$ signal as a function of percentage inhibition of $\alpha-\mathrm{KGDH}$ and aconitase, obtained in the presence of different concentrations of $\mathrm{H}_{2} \mathrm{O}_{2}(10-500 \mu \mathrm{M})$. This Figure indicates a lack of correlation between aconitase activity and $\mathrm{NAD}(\mathrm{P}) \mathrm{H}$ level; inhibition of the enzyme by $86.5 \pm 1.3 \%$ in the presence of $25 \mu \mathrm{M} \mathrm{H}_{2} \mathrm{O}_{2}$ was not associated with any alteration in the $\mathrm{NAD}(\mathrm{P}) \mathrm{H}$ signal, whereas a decrease in the $\mathrm{NAD}(\mathrm{P}) \mathrm{H}$ level was seen at high concentrations of $\mathrm{H}_{2} \mathrm{O}_{2}$ when aconitase was completely inactivated $(50-500 \mu \mathrm{M})$. By contrast, inhibition of $\alpha$-KGDH in the presence of $50-500 \mu \mathrm{M} \mathrm{H} \mathrm{H}_{2} \mathrm{O}_{2}$ appeared to correlate with a decrease in the $\mathrm{NAD}(\mathrm{P}) \mathrm{H}$ level, suggesting that inhibition of this enzyme could be a crucial factor in limiting the NADH production in the Krebs cycle during oxidative stress induced by 100-500 $\mathrm{MM} \mathrm{H}_{2} \mathrm{O}_{2}$.

\section{Decrease in the amount of glutamate by $\mathrm{H}_{2} \mathrm{O}_{2}$}

In nerve terminals it has been reported that in the absence of glucose, the flux in the Krebs cycle is partially maintained (Yudkoff et al., 1994; Erecinska et al., 1996), most likely resulting from a supply of $\alpha$-ketoglutarate from glutamate by aspartate aminotransferase (Yudkoff et al., 1994).

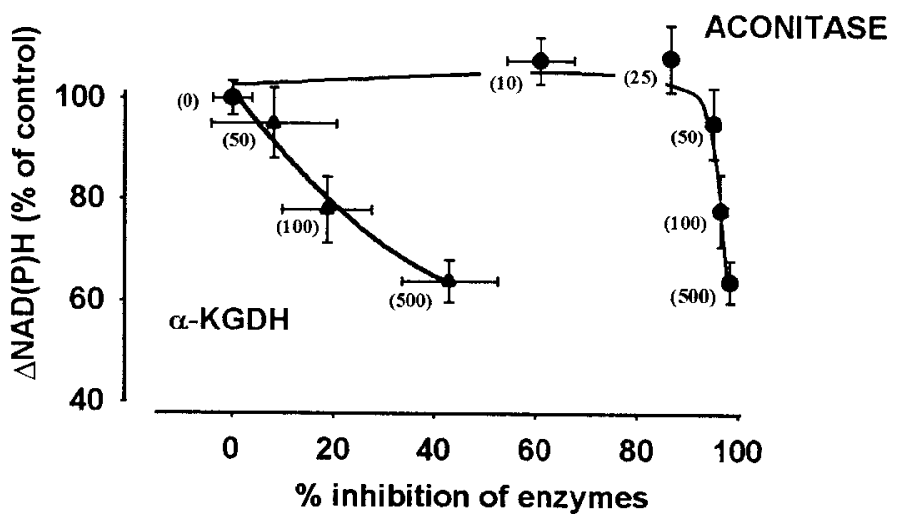

Figure 5. Relationship between inhibition of aconitase or $\alpha-\mathrm{KGDH}$ and decrease in the rotenone-induced NAD $(\mathrm{P}) \mathrm{H}$ fluorescence. Decreases in the rotenone-induced $\mathrm{NAD}(\mathrm{P}) \mathrm{H}$ signal (data in Fig. 4, curve $b$ ) are shown as a function of percentage inhibition of aconitase (derived from Fig. 1) or $\alpha$-KGDH (from Fig. 2a) as measured after incubation with $\mathrm{H}_{2} \mathrm{O}_{2}$ for 5 min. $\mathrm{H}_{2} \mathrm{O}_{2}$ concentrations (in micromoles) are indicated in brackets. We have shown in separate control experiments (data not shown) that BCNU at 200 $\mu \mathrm{M}$ concentration has no effect on the activities of aconitase or $\alpha$-KGDH, nor does it influence the effect of $\mathrm{H}_{2} \mathrm{O}_{2}$ on these enzymes. Data are average of five [for NAD(P)H measurement] or eight (for enzyme assays) determinations \pm SEM.

To determine whether glutamate could be used as a metabolite under oxidative stress, we measured the glutamate content in synaptosomes. The effect of $\mathrm{H}_{2} \mathrm{O}_{2}$ and of a glucose-free condition were similar: both resulted in a decrease in the total glutamate content (Table 4). $\mathrm{H}_{2} \mathrm{O}_{2}$ at 50 and $500 \mu \mathrm{M}$ concentrations decreased the glutamate level, and after $20 \mathrm{~min}, 50 \%$ of the total glutamate content was lost. At lower $\mathrm{H}_{2} \mathrm{O}_{2}$ concentrations, the amount of glutamate was unchanged $(5 \mu \mathrm{M})$ or only slightly decreased $(10 \mu \mathrm{M})$ (Table 4). Because glutamate was measured in samples containing synaptosomes and the medium in which the incubation was performed (see Materials and Methods), the results obtained reflect a net loss in the amount of glutamate and are unrelated to release of glutamate from nerve terminals.

These results indicate that during exposure to $\mathrm{H}_{2} \mathrm{O}_{2}$, glutamate in nerve terminals could serve as an alternative metabolite when 
Table 4. Effects of $\mathrm{H}_{2} \mathrm{O}_{2}$ and glucose-free medium on the glutamate content of synaptosomes

Glutamate (nmol/mg protein)

\begin{tabular}{lllr} 
& $0 \mathrm{~min}$ & $10 \min$ & \multicolumn{1}{c}{$20 \mathrm{~min}$} \\
\hline Control & $36.1 \pm 3.2$ & $34.5 \pm 2.4$ & $35.9 \pm 2.2$ \\
$\mathrm{H}_{2} \mathrm{O}_{2}(5 \mu \mathrm{M})$ & $\mathrm{ND}$ & $34.5 \pm 3$ & $33.6 \pm 5.1$ \\
$\mathrm{H}_{2} \mathrm{O}_{2}(10 \mu \mathrm{M})$ & $\mathrm{ND}$ & $29.3 \pm 2.1$ & $28.3 \pm 1.7^{a}$ \\
$\mathrm{H}_{2} \mathrm{O}_{2}(50 \mu \mathrm{M})$ & $36.2 \pm 1.8$ & $24.4 \pm 1.4^{a}$ & $18 \pm 1.5^{a}$ \\
$\mathrm{H}_{2} \mathrm{O}_{2}(500 \mu \mathrm{M})$ & $31.6 \pm 4.3$ & $20.6 \pm 1.9^{a}$ & $18.2 \pm 1.8^{a}$ \\
- Glucose & $30.9 \pm 3.7$ & $25.1 \pm 5.8^{a}$ & $16.9 \pm 0.5^{a}$ \\
\hline
\end{tabular}

Synaptosomes were incubated in the presence or absence of $\mathrm{H}_{2} \mathrm{O}_{2}$ or in glucose-free medium as indicated. After different lengths of time, aliquots were taken, and glutamate content was measured as described in Materials and Methods. Each point represents a mean \pm SEM of four experiments performed in duplicate.

${ }^{a}$ Significantly different from the corresponding controls $(p<0.005)$.

the normal flux in the Krebs cycle is blocked because of inactivation of aconitase. In this respect, the effect of a shortage in glucose supply and $\mathrm{H}_{2} \mathrm{O}_{2}$-induced oxidative stress appears to be similar.

\section{DISCUSSION}

To make a correct estimate of the $\mathrm{H}_{2} \mathrm{O}_{2}$-induced changes in the formation of $\mathrm{NADH}$, it is crucial to establish the extent to which changes in the fluorescence of NAD $(\mathrm{P}) \mathrm{H}$ represent changes in the level of NADH. The NAD-NADH/NADP-NADPH ratio in synaptosomes is $\sim 10: 1$ (Table 3 ), in agreement with data for whole brain (Siesjö et al., 1995) and for different brain regions (Klaidman et al., 1995); therefore, it is reasonable to assume that fluorescence of NADPH makes only a small contribution to the total fluorescence monitored at $344 \mathrm{~nm}$. In addition, in the present study the rotenone-induced increase in the $\mathrm{NAD}(\mathrm{P}) \mathrm{H}$ fluorescence was studied and could be interpreted as an indication primarily of the level of NADH available for the respiratory chain. Although this reasoning is correct, the possibility should be considered that a significant fraction of NADH could be used to regenerate NADPH when an increased demand is imposed by $\mathrm{H}_{2} \mathrm{O}_{2}$. This was indeed indicated by the result that inhibition of glutathione reductase by BCNU partly prevented the $\mathrm{H}_{2} \mathrm{O}_{2}$-induced decline in the rotenone-induced NAD $(\mathrm{P}) \mathrm{H}$ signal (Fig. 4). Thus an increased consumption of NADPH in the glutathione peroxidase-reductase system to eliminate $\mathrm{H}_{2} \mathrm{O}_{2}$ appears to drain part of the NADH present in nerve terminals; i.e., some NADPH is regenerated at the expense of NADH. We have not addressed the mechanisms by which this could occur, but the conclusion is compatible with findings that mitochondria from rat forebrain contain $\mathrm{NADP}^{+}$dependent isocitrate dehydrogenase, malic enzyme, and nicotinamide nucleotide transhydrogenase, which contribute to the regeneration of NADPH (Vogel et al., 1999).

The BCNU-insensitive decrease in NAD $(\mathrm{P}) \mathrm{H}$ signal induced by $\mathrm{H}_{2} \mathrm{O}_{2}$ could be taken as a reflection of changes in the NADH level that are unrelated to NADPH consumption by glutathione reductase (Fig. 4, curve b). Because rotenone was applied to prevent oxidation of NADH in the respiratory chain, these changes could mirror primarily changes in the formation of NADH. The present results show that generation of NADH could be impaired by $\mathrm{H}_{2} \mathrm{O}_{2}$ only when present in $>50 \mu \mathrm{M}$ concentrations. Decreases in the $\mathrm{NAD}(\mathrm{P}) \mathrm{H}$ fluorescence at lower concentrations of the oxidant $(10-50 \mu \mathrm{M})$ were completely prevented by BCNU, which could be attributed to an increased utilization of NADPH by glutathione reductase.

The question arises as to what could limit the formation of $\mathrm{NADH}$ during $\mathrm{H}_{2} \mathrm{O}_{2}$-induced oxidative stress. The result that omission of glucose (in the presence or absence of 2-deoxyglucose) in the medium had essentially no effect on the decrease in the NAD $(\mathrm{P}) \mathrm{H}$ signal induced by $\mathrm{H}_{2} \mathrm{O}_{2}$ suggests that inhibition of glycolysis by the oxidant does not contribute to the effect (Table 2). This shows that the inhibition of glyceraldehyde-3-phosphate de- hydrogenase reported previously (Hyslop et al., 1988; Janero et al., 1993) makes no contribution to the decline in NAD(P)H signal induced by $\mathrm{H}_{2} \mathrm{O}_{2}$ in nerve terminals. Because we also found that $\mathrm{H}_{2} \mathrm{O}_{2}(50-500 \mu \mathrm{M})$ induced no alteration in the activity of pyruvate dehydrogenase (data not shown), formation of NADH in the Krebs cycle needs to be considered in interpreting the effect of $\mathrm{H}_{2} \mathrm{O}_{2}$ on the rotenone-induced $\mathrm{NAD}(\mathrm{P}) \mathrm{H}$ signal.

We demonstrate in this work that three enzymes in the Krebs cycle could be inhibited by $\mathrm{H}_{2} \mathrm{O}_{2}$ : aconitase, $\alpha-\mathrm{KGDH}$, and succinate dehydrogenase. The overall rate of the Krebs cycle is considered to be determined by the activities of citrate synthase, isocitrate dehydrogenase, and $\alpha$-KGDH (Cooney et al., 1981; McCormack et al., 1990; Moreno-Sanchez et al., 1990). However, Yudkoff et al. (1994) determined in an elaborate study the flux through two segments of the Krebs cycle in nerve terminals-that between $\alpha$-ketoglutarate and oxaloacetate and that between oxaloacetate and $\alpha$-ketoglutarate - and established that the Krebs cycle does not always function as a single unified entity. They also suggested that the overall rate-controlling reaction of the cycle involves either citrate synthase or pyruvate dehydrogenase (Yudkoff et al., 1994). In our study, neither of these enzymes was found to be influenced by $\mathrm{H}_{2} \mathrm{O}_{2}$. In this portion of the cycle (between oxaloacetate and $\alpha$-ketoglutarate), only aconitase was vulnerable to inhibition by $\mathrm{H}_{2} \mathrm{O}_{2}$ (Fig. 1), showing a complete inactivation at $50 \mu \mathrm{M} \mathrm{H}_{2} \mathrm{O}_{2}$ or higher.

In the segment between $\alpha$-ketoglutarate and oxaloacetate, $\alpha$-KGDH is the slowest enzyme $\left(14 \pm 1.2 \mathrm{nmol} \cdot \mathrm{min}^{-1} \cdot \mathrm{mg}^{-1}\right.$ in this study) and is considered to have a flux-controlling function (Hansford, 1980; Yudkoff et al., 1994). We found that this enzyme is inhibited by $\mathrm{H}_{2} \mathrm{O}_{2}$, and for this, higher concentrations of $\mathrm{H}_{2} \mathrm{O}_{2}$ are required than those inhibiting aconitase; i.e., aconitase is a more vulnerable target for $\mathrm{H}_{2} \mathrm{O}_{2}$ in the Krebs cycle than is $\alpha-\mathrm{KGDH}$. Aconitase was reported to be inactivated by $\mathrm{O}_{2}{ }^{-}$(Gardner and Fridovich, 1992; Gardner et al., 1995), and inhibition of aconitase has been suggested to be a sensitive marker of intracellular superoxide generation in mammalian cells (Gardner et al., 1995; Patel et al., 1996). Our finding that aconitase is inhibited by $\mathrm{H}_{2} \mathrm{O}_{2}$, although corroborating that this enzyme is a sensitive marker of oxidative stress (Gardner and Fridovich, 1992; Gardner et al., 1995; Patel et al., 1996), indicates that inhibition of aconitase does not permit the identification of the type of reactive oxygen species involved in oxidative stress.

Although aconitase is not considered to be a rate-controlling enzyme and is not involved directly in NADH generation, when it is completely inactivated the whole cycle could be blocked. We found, however, that the rotenone-induced NAD $(\mathrm{P}) \mathrm{H}$ fluorescence, i.e., NADH level available for the respiratory chain, was not significantly changed even when aconitase was inhibited by $100 \%$ with $50 \mu \mathrm{M} \mathrm{H}_{2} \mathrm{O}_{2}$ (Fig. 5). In the presence of inactivated aconitase, $\mathrm{NAD}(\mathrm{P}) \mathrm{H}$ fluorescence decreased only when $\alpha-\mathrm{KGDH}$ was also inhibited (at higher $\mathrm{H}_{2} \mathrm{O}_{2}$ concentrations). It follows from this finding that in the complete absence of aconitase, the NADH supply for the respiratory chain can be maintained; thus a segment of the Krebs cycle must be functional.

It has been observed that in the absence of glucose the flux in the segment between $\alpha$-ketoglutarate and oxaloacetate is accelerated, indicating that alternative substrate(s) entering at $\alpha$-ketoglutarate could operate this portion of the Krebs cycle (Yudkoff et al., 1994; Erecinska et al., 1996). Our finding that in the absence of glucose the NAD $(\mathrm{P}) \mathrm{H}$ fluorescence was unchanged (Table 2) is consistent with this suggestion. It has also been suggested (Yudkoff et al., 1994) that glutamate, which is present at a level of $44 \mathrm{nmol} / \mathrm{mg}$ in nerve terminals (Erecinska et al., 1988) and can be converted to $\alpha$-ketoglutarate, is the most likely metabolite fueling the Krebs cycle in the absence of glucose. We found that $\mathrm{H}_{2} \mathrm{O}_{2}$ significantly decreased the amount of glutamate present in nerve terminals, similarly to the glucose-free condition, but only at concentrations at which aconitase was inhibited to a large extent (Table 4). This indicates that a similar mechanism could operate under glucosefree conditions and exposure to $\mathrm{H}_{2} \mathrm{O}_{2}$, when aconitase is inhibited. 
a) LOW CONCENTRATIONS OF $\mathrm{H}_{2} \mathrm{O}_{2}$ $(\leq 50 \mu \mathrm{M})$

\section{b) HIGH CONCENTRATIONS OF $\mathrm{H}_{2} \mathrm{O}_{2}$} $(\geq 100 \mu \mathrm{M})$

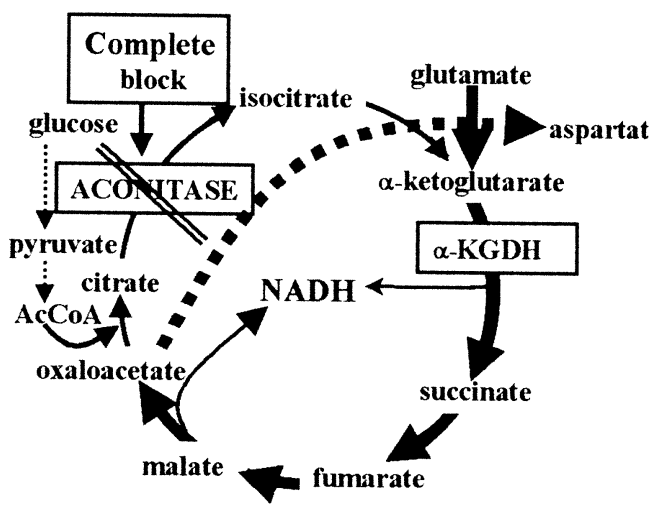

NORMAL NADH GENERATION

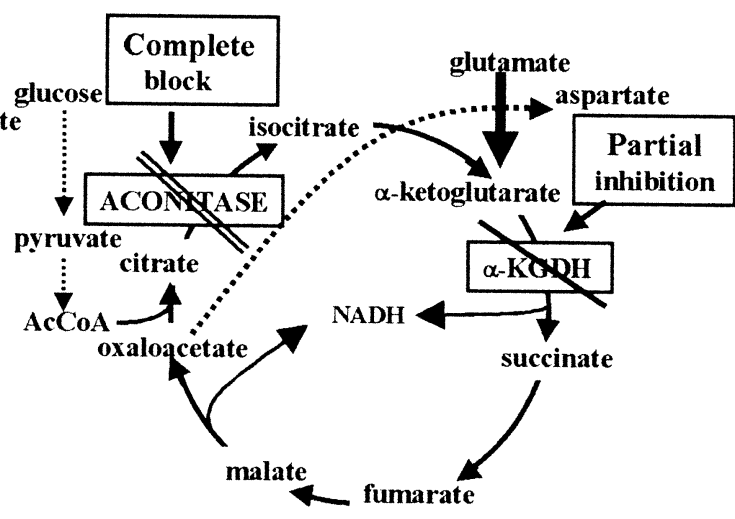

IMPAIRED NADH GENERATION

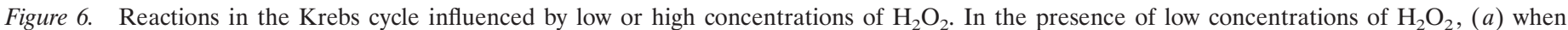

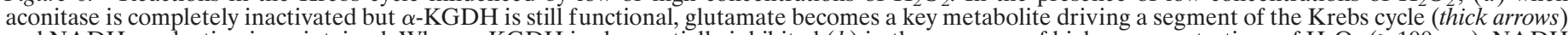

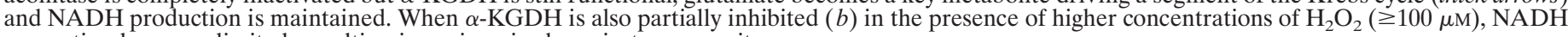
generation becomes limited, resulting in an impaired respiratory capacity.

It can be concluded that glutamate is likely to be converted to $\alpha$-ketoglutarate under $\mathrm{H}_{2} \mathrm{O}_{2}$-induced oxidative stress. In the early stage of an oxidative stress, this mechanism would rescue a segment of the Krebs cycle when aconitase is already nearly completely inactivated (thus formation of $\alpha$-ketoglutarate from citrate is limited) but $\alpha-\mathrm{KGDH}$ is still functional. Only when $\alpha-\mathrm{KGDH}$ is inhibited at higher concentrations of the oxidant $(>50 \mu \mathrm{M})$ is the production of NADH compromised (Fig. 5). Because aspartate aminotransferase, but not glutamate dehydrogenase, has a high activity in this preparation (Cheeseman and Clark, 1988; Yudkoff et al., 1994), transamination could be the primary mechanism by which glutamate is converted to $\alpha$-ketoglutarate. The possible pathways operating in the presence of $\mathrm{H}_{2} \mathrm{O}_{2}$ are outlined in Figure 6.

In summary, the conclusions of the present work are as follows. (1) Aconitase is the most sensitive enzyme to $\mathrm{H}_{2} \mathrm{O}_{2}$ in the Krebs cycle, but inhibition of $\alpha-\mathrm{KGDH}$ plays a critical role in limiting the amount of NADH during $\mathrm{H}_{2} \mathrm{O}_{2}$-induced oxidative stress. (2) An increased conversion of NADH to NADPH to supply reducing equivalents for the elimination of $\mathrm{H}_{2} \mathrm{O}_{2}$ makes a contribution to the decrease in NADH level. (3) In the early stage of an $\mathrm{H}_{2} \mathrm{O}_{2}$-induced oxidative stress, glutamate could be used as a metabolite to maintain NADH production in a segment of the Krebs cycle.

This study highlights the significance of $\alpha-\mathrm{KGDH}$ in conditions involving oxidative stress. Recently it has been reported that peroxinitrate in microglia (Park et al., 1999) and 4-hydroxy-2-nonenal (HNE), a product of lipid peroxidation, in isolated cardiac mitochondria inhibited $\alpha-\mathrm{KGDH}$ and reduced NADH production initiated by addition of $\alpha$-ketoglutarate (Humphries et al., 1998). $\mathrm{H}_{2} \mathrm{O}_{2}$ is a relatively mild insult, which in the early stage of the oxidative stress $(<30 \mathrm{~min})$ is not associated with peroxidation of membrane lipids (Tretter and Adam-Vizi, 1996), thus the formation of HNE.

$\alpha$-KGDH also exhibited a reperfusion-induced age-dependent inactivation in mitochondria prepared from rat heart after exposure to ischemia/reperfusion (Lucas and Szweda, 1999). This could be related to an effect of $\mathrm{H}_{2} \mathrm{O}_{2}$ given that during microdialysis, $\mathrm{H}_{2} \mathrm{O}_{2}$ at $0.1 \mathrm{~mm}$ concentration is formed in the striatum during reperfusion after an ischemic period (Hyslop et al., 1995). High concentrations of $\mathrm{H}_{2} \mathrm{O}_{2}$ can also be reached in aged brain (Sohal et al., 1994; Auerbach and Segal, 1997). The critical role of inhibition of $\alpha-\mathrm{KGDH}$ by $\mathrm{H}_{2} \mathrm{O}_{2}$ revealed in this study could be important in the pathogenesis of late-onset neurodegenerative diseases such as Parkinson's disease (Mizuno et al., 1994) and Alzheimer's disease (Blass and Gibson, 1991; Gibson et al., 1998a), during which the activity of $\alpha$-KGDH was found to be inhibited (for review, see
Gibson et al., 2000). The sensitivity of $\alpha$ KGDH in nerve terminals could be particularly relevant to the suggestion that nerve terminals are the primary site of mitochondrial damage in Alzheimer's neurons (Sumpter et al., 1986; Blass and Gibson, 1991).

With a limited function of $\alpha-\mathrm{KGDH}$, mitochondria in nerve terminals are likely to be unable to meet the energy demand imposed by neuronal activity, eventually leading to impaired function. This was indicated in our previous finding that under an $\mathrm{H}_{2} \mathrm{O}_{2}$-induced oxidative stress, an increased energy demand induced a complete functional collapse of nerve terminals (Chinopoulos et al., 2000).

\section{REFERENCES}

Ahmad T, Frischer H (1985) Active site-specific inhibition by 1,3-bis(2chloroethyl)-1-nitrosourea of two genetically homologous flavoenzymes: glutathione reductase and lipoamide dehydrogenase. J Lab Clin Med 105:464-471.

Andersson U, Leighton B, Young ME, Blomstrand E, Newsholme EA (1998) Inactivation of aconitase and oxoglutarate dehydrogenase in skeletal muscle in vitro by superoxide anions and/or nitric oxide. Biochem Biophys Res Commun 249:512-516.

Auerbach JM, Segal M (1997) Peroxide modulation of slow onset potentiation in rat hippocampus. J Neurosci 17:8695-8701.

Beal MF (1996) Mitochondria, free radicals, and neurodegeneration. Curr Opin Neurobiol 6:661-666.

Becker K, Schirmer RH (1995) 1,3-Bis(2-chloroethyl)-1-nitrosourea as thiol-carbamoylating agent in biological systems. Methods Enzymol 251:173-188.

Bernofsky C, Swan M (1973) An improved cycling assay for nicotinamide adenine dinucleotide. Anal Biochem 53:452-458.

Blass JP, Gibson GE (1991) The role of oxidative abnormalities in the pathophysiology of Alzheimer's disease. Rev Neurol (Paris) 147:513-525.

Boveris A, Oshino N, Chance B (1972) The cellular production of hydrogen peroxide. Biochem J 128:617-630.

Carlberg I, Mannervik B (1985) Glutathione reductase. Methods Enzymol 113:484-490.

Cheeseman AJ, Clark JB (1988) Influence of the malate-aspartate shuttle on oxidative metabolism in synaptosomes. J Neurochem 50:1559-1565.

Chinopoulos C, Tretter L, Adam-Vizi V (1999) Depolarization of in situ mitochondria due to hydrogen peroxide-induced oxidative stress in nerve terminals: inhibition of alpha-ketoglutarate dehydrogenase. J Neurochem 73:220-228.

Chinopoulos C, Tretter L, Rozsa A, Adam-Vizi V (2000) Exacerbated responses to oxidative stress by an $\mathrm{Na}^{+}$load in isolated nerve terminals: the role of ATP depletion and rise of $\left[\mathrm{Ca}^{2+}\right]_{\mathrm{i}}$. J Neurosci 20:2094-2103.

Cino M, Del Maestro RF (1989) Generation of hydrogen peroxide by brain mitochondria: the effect of reoxygenation following postdecapitative ischemia. Arch Biochem Biophys 269:623-638.

Cooney GJ, Taegtmeyer H, Newsholme EA (1981) Tricarboxylic acid cycle flux and enzyme activities in the isolated working rat heart. Biochem J 200:701-703. 
Desagher S, Glowinski J, Premont J (1996) Astrocytes protect neurons from hydrogen peroxide toxicity. J Neurosci 16:2553-2562.

Dringen R, Kussmaul L, Gutterer JM, Hirrlinger J, Hamprecht B (1999) The glutathione system of peroxide detoxification is less efficient in neurons than in astroglial cells. J Neurochem 72:2523-2530.

Dykens JA (1994) Isolated cerebral and cerebellar mitochondria produce free radicals when exposed to elevated $\mathrm{Ca}^{2+}$ and $\mathrm{Na}^{+}$: implications for neurodegeneration. J Neurochem 63:584-591.

Erecinska M, Zaleska MM, Nissim I, Nelson D, Dagani F, Yudkoff M (1988) Glucose and synaptosomal glutamate metabolism: studies with [15N]glutamate. J Neurochem 51:892-902.

Erecinska M, Nelson D, Silver IA (1996) Metabolic and energetic properties of isolated nerve ending particles (synaptosomes). Biochim Biophys Acta 1277:13-34.

Gardner AM, Xu FH, Fady C, Jacoby FJ, Duffey DC, Tu Y, Lichtenstein A (1997) Apoptotic vs. nonapoptotic cytotoxicity induced by hydrogen peroxide. Free Radic Biol Med 22:73-83.

Gardner PR, Fridovich I (1992) Inactivation-reactivation of aconitase in Escherichia coli. A sensitive measure of superoxide radical. J Biol Chem 267:8757-8763.

Gardner PR, Raineri I, Epstein LB, White CW (1995) Superoxide radical and iron modulate aconitase activity in mammalian cells. J Biol Chem 270:13399-13405.

Gibson GE, Sheu KF, Blass JP (1998a) Abnormalities of mitochondrial enzymes in Alzheimer disease. J Neural Transm 105:855-870.

Gibson GE, Zhang H, Sheu KF, Bogdanovich N, Lindsay JG, Lannfelt L, Vestling M, Cowburn RF (1998b) Alpha-ketoglutarate dehydrogenase in Alzheimer brains bearing the APP670/671 mutation. Ann Neurol 44:676-681.

Gibson GE, Park LC, Sheu KF, Blass JP, Calingasan NY (2000) The alpha-ketoglutarate dehydrogenase complex in neurodegeneration. Neurochem Int 36:97-112.

Hansford RG (1980) Control of mitochondrial substrate oxidation. In: Current topics in bioenergetics (Sanadi DR, ed), pp 217-278. New York: Academic.

Hausladen A, Fridovich I (1996) Measuring nitric oxide and superoxide: rate constants for aconitase reactivity. Methods Enzymol 269:37-41.

Hinman LM, Blass JP (1981) An NADH-linked spectrophotometric assay for pyruvate dehydrogenase complex in crude tissue homogenates. J Biol Chem 256:6583-6586.

Humphries KM, Yoo Y, Szweda LI (1998) Inhibition of NADH-linked mitochondrial respiration by 4-hydroxy-2-nonenal. Biochemistry 37:552-557.

Hyslop PA, Hinshaw DB, Halsey Jr WA, Schraufstatter IU, Sauerheber RD, Spragg RG, Jackson JH, Cochrane CG (1988) Mechanisms of oxidant-mediated cell injury. The glycolytic and mitochondrial pathways of ADP phosphorylation are major intracellular targets inactivated by hydrogen peroxide. J Biol Chem 263:1665-1675.

Hyslop PA, Zhang Z, Pearson DV, Phebus LA (1995) Measurement of striatal $\mathrm{H}_{2} \mathrm{O}_{2}$ by microdialysis following global forebrain ischemia and reperfusion in the rat: correlation with the cytotoxic potential of $\mathrm{H}_{2} \mathrm{O}_{2}$ in vitro. Brain Res 671:181-186.

Janero DR, Hreniuk D, Sharif HM, Prout KC (1993) Hydroperoxideinduced oxidative stress alters pyridine nucleotide metabolism in neonatal heart muscle cells. Am J Physiol 264:C1401-C1410.

Kitto GB (1969) Intra- and extramitochondrial malate dehydrogenases from chicken and tuna heart. Methods Enzymol XIII:106-116.

Klaidman LK, Leung AC, Adams Jr JD (1995) High-performance liquid chromatography analysis of oxidized and reduced pyridine dinucleotides in specific brain regions. Anal Biochem 228:312-317.

Klingenberg M (1974) Nicotinamid-adenin-dinucleotide (NAD, NADP, $\mathrm{NADH}, \mathrm{NADPH}$ ) spektrofotometrische and fluorimetrische verfahren. In: Methoden der Enzymetischen Analyse (Bergmeyer HU, ed), pp 2094-2108. Weinheim: Verlag Chemie.

Lai JC, Cooper AJ (1986) Brain alpha-ketoglutarate dehydrogenase complex: kinetic properties, regional distribution, and effects of inhibitors. J Neurochem 47:1376-1386.

Loschen G, Azzi A, Richter C, Flohe L (1974) Superoxide radicals as precursors of mitochondrial hydrogen peroxide. FEBS Lett 42:68-72.

Lucas DT, Szweda LI (1999) Declines in mitochondrial respiration during cardiac reperfusion: age-dependent inactivation of alpha-ketoglutarate dehydrogenase. Proc Natl Acad Sci USA 96:6689-6693.

McCormack JG, Halestrap AP, Denton RM (1990) Role of calcium ions in regulation of mammalian intramitochondrial metabolism. Physiol Rev 70:391-425.
Mizuno Y, Matuda S, Yoshino H, Mori H, Hattori N, Ikebe S (1994) An immunohistochemical study on alpha-ketoglutarate dehydrogenase complex in Parkinson's disease. Ann Neurol 35:204-210.

Moreno-Sanchez R, Hogue BA, Hansford RG (1990) Influence of NADlinked dehydrogenase activity on flux through oxidative phosphorylation. Biochem J 268:421-428.

Nisselbaum JS, Green S (1969) A simple ultramicro method for determination of pyridine nucleotides in tissues. Anal Biochem 27:212-217.

Nohl H, Jordan W, Hegner D (1981) Identification of free hydroxyl radicals in respiring rat heart mitochondria by spin trapping with the nitrone DMPO. FEBS Lett 123:241-244.

Olanow CW (1993) A radical hypothesis for neurodegeneration. Trends Neurosci 16:439-444.

Park LC, Zhang H, Sheu KF, Calingasan NY, Kristal BS, Lindsay JG, Gibson GE (1999) Metabolic impairment induces oxidative stress, compromises inflammatory responses, and inactivates a key mitochondrial enzyme in microglia. J Neurochem 72:1948-1958.

Patel M, Day BJ, Crapo JD, Fridovich I, McNamara JO (1996) Requirement for superoxide in excitotoxic cell death. Neuron 16:345-355.

Phillis JW (1994) A "radical" view of cerebral ischemic injury. Prog Neurobiol 42:441-448.

Scanlon JM, Reynolds IJ (1998) Effects of oxidants and glutamate receptor activation on mitochondrial membrane potential in rat forebrain neurons. J Neurochem 71:2392-2400.

Schapira AH (1994) Mitochondrial dysfunction in neurodegenerative disorders and aging. In: Mitochondrial disorder in neurology (Schapira AH, DiMauro S, eds), pp 227-244. Oxford: Butterworth-Heinemann.

Siesjö BK, Pahlmark K, Siesjö P, Katsura K-I, Folbergova J (1995) Glutamate, calcium, and free radicals as mediators of ischemic brain damage. Ann Thorac Surg 59:1316-1320.

Sohal RS, Ku H, Agarwal S, Forster MJ, Lal H (1994) Oxidative damage, mitochondrial oxidant generation and antioxidant defences during aging and in food restriction in the mouse. Mech Ageing Dev 74:121-133.

Srere PA (1969) Citrate synthase. In: Methods in enzymology, citric acid cycle (Lowenstein JM, ed), pp 3-11. New York: Academic.

Sumpter PQ, Mann DM, Davies CA, Yates PO, Snowden JS, Neary D (1986) An ultrastructural analysis of the effects of accumulation of neurofibrillary tangle in pyramidal neurons of the cerebral cortex in Alzheimer's disease. Neuropathol Appl Neurobiol 12:305-319.

Tan AK, Ramsay RR, Singer TP, Miyoshi H (1993) Comparison of the structures of the quinone-binding sites in beef heart mitochondria. J Biol Chem 268:19328-19333.

Tretter L, Adam-Vizi V (1996) Early events in free radical-mediated damage of isolated nerve terminals: effects of peroxides on membrane potential and intracellular $\mathrm{Na}^{+}$and $\mathrm{Ca}^{2+}$ concentrations. J Neurochem 66:2057-2066.

Tretter L, Szabados G, Ando A, Horvath I (1987) Effect of succinate on mitochondrial lipid peroxidation. The protective effect of succinate against functional and structural changes induced by lipid peroxidation. J Bioenerg Biomembr 19:31-44.

Tretter L, Chinopoulos C, Adam-Vizi V (1997) Enhanced depolarizationevoked calcium signal and reduced [ATP]/[ADP] ratio are unrelated events induced by oxidative stress in synaptosomes. J Neurochem 69:2529-2537.

Vogel R, Wiesinger H, Hamprecht B, Dringen R (1999) The regeneration of reduced glutathione in rat forebrain mitochondria identifies metabolic pathways providing the NADPH required. Neurosci Lett 275:97-100.

Wang GJ, Thayer SA (1996) Sequestration of glutamate-induced $\mathrm{Ca}^{2+}$ loads by mitochondria in cultured rat hippocampal neurons. J Neurophysiol 76:1611-1621.

White RJ, Reynolds IJ (1996) Mitochondrial depolarization in glutamatestimulated neurons: an early signal specific to excitotoxin exposure. J Neurosci 16:5688-5697.

Yudkoff M, Nelson D, Daikhin Y, Erecinska M (1994) Tricarboxylic acid cycle in rat brain synaptosomes. Fluxes and interactions with aspartate aminotransferase and malate/aspartate shuttle. J Biol Chem 269:27414-27420.

Zhang Y, Lipton P (1999) Cytosolic $\mathrm{Ca}^{2+}$ changes during in vitro ischemia in rat hippocampal slices: major roles for glutamate and $\mathrm{Na}^{+}$. dependent $\mathrm{Ca}^{2+}$ release from mitochondria. J Neurosci 19:3307-3315.

Zhang Y, Marcillat O, Giulivi C, Ernster L, Davies KJ (1990) The oxidative inactivation of mitochondrial electron transport chain components and ATPase. J Biol Chem 265:16330-16336. 